\title{
Effect of Musa spp. extract on eggs and larvae of gastrointestinal nematodes from infected sheep
}

\section{Efeito do extrato de Musa spp. sobre ovos e larvas de nematódeos gastrintestinais provenientes de ovinos infectados}

\author{
Natalie Neuwirt ${ }^{1}$; Lilian Gregory ${ }^{2 *}$; \\ Eidi Yoshihara ${ }^{3}$; Silvana Lima Gorniak ${ }^{2}$
}

\begin{abstract}
Resumo
As helmintoses figuram como um dos principais entraves para o desenvolvimento da caprinoovinocultura. Haemonchus contortus é a espécie que causa maior impacto nesta atividade pecuária. A resistência às drogas antiparasitárias e a procura por alimentos de origem animal livre de resíduos tem elevado a importância de tratamentos fitoterápicos. O objetivo desse trabalho foi desenvolver um extrato de Musa spp. e avaliar através de testes in vitro o efeito anti-helmíntico sobre ovos e larvas de nematódeos gastrintestinais de ovinos. Foram colhidas amostras de fezes de ovinos, naturalmente infectados, para a obtenção de ovos e larvas, seguida pela realização do teste da eclodibilidade de ovos e o teste de inibição da migração larval. Nos testes in vitro foram observados a inibição da eclodibilidade larval nas concentrações de 160 e $180 \mathrm{mg} \mathrm{mL}^{-1}$ de extrato e a inibição da migração larval nas concentrações de 800 e $1000 \mathrm{mg} \mathrm{mL}^{-1}$. Os resultados indicam que o uso da folha de bananeira tem efeito anti-helmíntico e estudos in vivo acerca da aplicabilidade dessa tecnologia a campo devem ser feitos a complementar e trazer maiores informações ao que já foi revelado no presente estudo.

Palavras-chave: Fitoterapia, Musa spp., clínica de ruminantes, resistência parasitária
\end{abstract}

\begin{abstract}
Helminthes are listed as one of the main problems facing the development of goat and sheep production. Haemonchus contortus is the specie that causes greatest negative impact in ranching. Resistance to antiparasitic drugs and demand for residue-free animal-derived food products has elevated the importance of herbal treatments. The aim of this study was to develop an extract of Musa spp. and assess by in vitro testing, the anthelmintic effect on eggs and larvae in the gastrointestinal nematodes in sheep. Stool samples from sheep naturally infected were used to obtain eggs and larvae and was then followed by a test of hatchability and a larval migration inhibition test. In vitro tests on the inhibition of larval hatchability at concentrations of 160 and $180 \mathrm{mg} \mathrm{mL}^{-1}$ of larval extracts and inhibition of migration at concentrations of 800 and $1000 \mathrm{mg} \mathrm{mL}^{-1}$ were observed. The results indicate that the use of banana leaf has an anthelmintic effect and that in vivo studies on the applicability of this technology to the field should be made to further understanding and bring more information to what has already been revealed in this study.
\end{abstract}

Key words: Phytotherapy, Musa spp., ruminant clinics, parasitary resistance

\footnotetext{
1 Discente do Curso de Graduação, Medicina Veterinária, da Faculdade de Medicina Veterinária e Zootecnia da Universidade de São Paulo, USP, São Paulo, SP, Brasil. E-mail: nat.trume@gmail.com

2 Profs. Drs., Faculdade de Medicina Veterinária e Zootecnia, USP, São Paulo, SP, Brasil. E-mail: lgregory@usp.br; gorniak@usp. br

3 Pesquisador, Agência Paulista de Tecnologia dos Agronegócios, Polo Regional Alta Sorocabana, APTA, Presidente Prudente, SP, Brasil. E-mail: eidi@apta.sp.gov.br

* Author for correspondence
} 


\section{Introduction}

With the intense and inappropriate use of anthelmintic in breeding, ranchers often miss waiting for the proper period of time between treatments, resistant helminth strains have been selected (FONSECA et al., 2014). The lack of epidemiological features, the relatively low cost of treatment and the massive use of antiparasitics by producers (BORGES et al., 2011) are increasing the cases of resistance.

The growth interest in herbal drugs with potential to be used as anthelmintic can be seen in the raise of studies about possible vegetable sources of active principles. Furtado et al. (2005), testing the action of tannin using C. papaya extracts and Musa paradisiaca (papaya and banana), concluded that there could be different outcomes in relation to other works depending on methodology.

According to Hoste et al. (2006), therapies with mineral or plant components, particularly the tannin, are options for future study of the strategic control of worms in ruminants. There are two theories that explain tannins efficiency. The first one focuses on the direct effect on the life cycle of helminthes and the second one on an indirect effect: the protein intake is protected from degradation in the rumen and increases its availability in the lower gastrointestinal tract (CEZAR et al., 2008). Human and Veterinary Medicine have used tannic acid for various therapeutic purposes and its effects are still being studied (AYRES; ALMEIDA, 2010). A literature review in 2007 (OLIVO et al., 2007) pointed to a lack of data about the use of plants as anthelmintic (particularly Musa spp.). In this literature review, the authors addressed the need for further multidisciplinary investigations in order to gather information on the palatability and consumption of the banana plant and also information related to species and animal category, and the degree of helminths control.

The interest in studying the herbal use of this plant for some authors has originated from recommendations of popular knowledge. Studying the medicinal use of plants from Cerrado, Bessa et al. (2013) used tannins as selection criteria and its properties were examined, although the paper did not specifically consider its anthelmintic potential. Furtado (2006) chose Genipa americana for in vitro tests, successfully using as criterion the fact that it was a plant rich in tannins. Schmahl et al. (2010) observed that Musa spp. influenced on motility of nematode larvae (Trichuris muris) when in contact with the fruit extract.

Regarding the efficiency of tanninipherous plants in combating helminths, there are studies tending to be developed around molecular and biochemical aspects of tannins. It has been proven that there are more effective combinations of monomers (BRUNET et al., 2008). One of the factors that can lead to different results is adhering to the methodology and source of active-principle. Nogueira et al. (2012) concluded in their in vitro tests that Musa spp was highly effective inhibiting the outbreak of Haemonchus contortus eggs.

As the great potential of using herbal as anthelmintic in livestock production, this study aimed to conduct the in vitro evaluation of Musa spp efficiency on larvae and eggs of gastrointestinal nematodes from naturally infected sheep.

\section{Material and Methods}

The alcohol extract of Musa spp., eggs and larvae acquisition

The process for making the alcohol extract started with fresh leaves harvested in properties in the city of São Paulo and stored covered in open spaces. Leaves were chopped into strips manually in the direction of the fibers, and placed in a laboratory oven at $40{ }^{\circ} \mathrm{C}$ (since higher temperatures would alter the viability of tannin, according to Silvana Gorniák $^{4}$.) After one day in the oven, the dried

\footnotetext{
4 Informação fornecida pela Professora Doutora Silvana Gorniák em 2009.
} 
leaves were ground in a medium-sized machine and the powder was placed immersed in absolute alcohol (1: 3 parts). Two days later, the resulting tincture was filtered through a paper filter, and then processed by rota-evaporator to concentrate. The resultant solution was stored in open containers back in the oven at $40{ }^{\circ} \mathrm{C}$ to complete the extract concentration process. Upon reaching the requisite pasty consistency, the extract pools were stored in the refrigerator.

The eggs and larvae utilized in the in vitro test were collected from a naturally infected sheep from the region of Londrina, which was kept in the isolation ward of the Londrina State University Veterinarian Hospital, receiving Musa-free diet. They received water and food (forage) ad libitum. The worms were monitored by examination of OPG and properly controlled for the preservation of health and animals welfare.

Feces were collected from the rectum. Eggs and fecal cultures were isolated to obtain thirdstage larvae (L3). The recovery of the eggs was performed according to the methodology described by Coles et al. (1992) adapted by Bizimenyera et al. (2006). The feces were homogenized in distilled water and filtered through a set of sieves. Eggs were retained in the $25 \mathrm{~mm}$ sieve, washed with distilled water and centrifuged at $1,100 \mathrm{x}$ g for $5 \mathrm{~min}$ in 50 $\mathrm{mL}$ tubes supplemented with water. The supernatant was discarded and saturated saline was added for resuspend the pellet. After further centrifugation under the same conditions, the supernatant was washed in a 25 um sieve. The collected eggs were stored in a sedimentation beaker for $2 \mathrm{~h}$. After syphoning, they were counted in five aliquots of $100 \mathrm{~mL}$.

\section{Egg hatch test}

No teste eclodibilidade de ovos, utilizou-se uma suspensão de ovos diluída em água destilada. Soluções do extrato foram preparadas utilizando- se DMSO e água destilada para diluição. As concentrações finais dos extratos foram $20 ; 40 ; 60$; $80 ; 100 ; 120 ; 140 ; 160$ e $180 \mathrm{mg} \mathrm{mL}^{-1}$.

In the Egg Hatch Test, the eggs were suspended in an extract solution containing DMSO and distilled water for dilution. The final concentrations of the extracts were $20,40,60,80,100,120,140,160$ and $180 \mathrm{mg} \mathrm{mL}^{-1}$. As a positive control, albendazole sulfoxide $\left(50 \mu \mathrm{g} \mathrm{mL}^{-1}\right.$, Ricofarm 10®, Biofarm) was used. Distilled water plus DMSO was used as negative control.

In performing the test, $100 \mu \mathrm{L}$ of suspension containing about 150 eggs was added in the wells of the plate for cell cultivation with three replicates for each treatment and control. $400 \mu \mathrm{L}$ of extracts at different concentrations were added. The plates were manually homogenized and put in BOD stove $\left(25{ }^{\circ} \mathrm{C}\right.$ and $\mathrm{RH}>80 \%$ ) for $48 \mathrm{~h}$. A drop of Lugol was added to each well, and eggs and $\mathrm{L}_{1}$ larvae from hatched eggs were quantified to calculate the percentage of inhibition of larval hatchability, according to the technique described by Coles et al. (1992).

\section{Larval migration inhibition assay}

The larval migration inhibition assay was conducted according to the methodology described by Rabel et al. (1994). Third stage larvae $\left(\mathrm{L}_{3}\right)$ were collected from fecal cultures obtained by naturally infected sheep. Approximately $150 \quad \mathrm{~L}_{3}$ were incubated at $27{ }^{\circ} \mathrm{C}$ in Eppendorf tubes containing $1 \mathrm{~mL}$ of the herbal extract diluted in distilled water and DMSO concentrations of 50,100, 200, 400, 600,800 and $1000 \mathrm{mg} \mathrm{mL}^{-1}$. The test was carried out with a negative (distilled water) and a positive (Levamisole Phosphate $-40 \mu \mathrm{g} \mathrm{mL}^{-1}$, Ripercol ${ }^{\circledR}$, Fort Dodge) control. After 3 hours of incubation, the tubes were centrifuged at $1,100 \mathrm{xg}$ for $2 \mathrm{~min}$. and the supernatant discarded leaving $200 \mu \mathrm{L} .1800 \mu \mathrm{L}$ of the diluted extract was added in concentrations above the wells of the cell culture plate of 24 wells, 
the test was carried out in sextuplicate. Then, the 22 $\mu \mathrm{m}$ mesh was placed into the wells and in the upper part of the mesh, $200 \mu \mathrm{L}$ of larval suspension was added using the respective concentrations tested. The plate was covered and placed in incubator chamber type BOD for $2 \mathrm{~h}$ at $27^{\circ} \mathrm{C}$.

\section{Results and Discussion}

The result of the Egg Hatch Test of gastrointestinal nematode eggs from sheep naturally infected, using alcoholic extract of Musa spp., is showed in Table 1, and the result of the Larval Migration Inhibition Assay of gastrointestinal nematodes eggs from sheep naturally infected, using alcoholic extract of Musa spp., in Table 2.

Table 1. Percentages of inhibition of hatching of gastrointestinal nematodes eggs from sheep per alcoholic extract concentration Musa spp. The significant inhibition was above 95\% (160 and $\left.180 \mathrm{mg} \mathrm{mL}^{-1}\right)$.

\begin{tabular}{cc}
\hline Concentrations & \% inhibition \\
\hline Negative control (distilled water) & 9,89 \\
$20 \mathrm{mg} \mathrm{mL}^{-1}$ & 26,93 \\
$40 \mathrm{mg} \mathrm{mL}^{-1}$ & 30,75 \\
$60 \mathrm{mg} \mathrm{mL}^{-1}$ & 41,33 \\
$80 \mathrm{mg} \mathrm{mL}^{-1}$ & 48,90 \\
$100 \mathrm{mg} \mathrm{mL}^{-1}$ & 58,63 \\
$120 \mathrm{mg} \mathrm{mL}^{-1}$ & 81,84 \\
$140 \mathrm{mg} \mathrm{mL}^{-1}$ & 89,43 \\
$160 \mathrm{mg} \mathrm{mL}^{-1}$ & 98,55 \\
$180 \mathrm{mg} \mathrm{mL}^{-1}$ & 100 \\
Positive control & 100 \\
\hline
\end{tabular}

For both hatchability and larval migration, the limit considered was $95 \%$ of inhibition. Hatchability of eggs and larval motility inhibition were successful using $160 \mathrm{mg} \mathrm{ml}^{-1}$ and $180 \mathrm{mg} \mathrm{ml}^{-1}$ and $800 \mathrm{mg} \mathrm{ml}^{-1}$ and $1000 \mathrm{mg} \mathrm{ml}^{-1}$ of extract, respectively.

The use of anthelmintics in under doses is an important problem associated with wrong management. As a result, strains of helminths (Haemonchus spp, Trichostrongylus spp and Ostertagia spp.) have been selected, as they are resistant to many commercial products (RAMOS et al., 2002). Thus, plant sources appear to be a good alternative for commercial anthelmintic. However, there is a lack of sufficient data to validate their use.
The present research proved that the in vitro use is efficient in both: Larval Migration Inhibition and Egg Hatch, for sheep worms. Thus, the tannin contained in Musa spp. would be suitable. Furtado et al. (2005) observed that there was no effectiveness against gastrointestinal nematodes of sheep, contradicting the results of the present work. This occurrence could be explained by the fact that the extracts were obtained from different sources: from Musa paradise flowers in the 2005 study and from a leaf pool (from the Musa spp.), in the current study. Furthermore, the plant processing in the current study did not exceed $40{ }^{\circ} \mathrm{C}$, while Furtado et al. (2005) reached a temperature up to $70{ }^{\circ} \mathrm{C}$, in which tannins would be degraded. This information demonstrates an important difference in methodology, as the author himself warned about the different results. 
Table 2. Percentage of $\mathrm{L}_{3}$ larvae (gastrointestinal nematodes from naturally infected sheep) migration by each alcoholic Musa spp extract concentration. The inhibition was considered significant when the inhibition of migration was above $95 \%$ ( 800 and $\left.1000 \mathrm{mg} \mathrm{mL}^{-1}\right)$.

\begin{tabular}{lc}
\hline Concentration & \% migration \\
\hline Negative control (distilled water) & 97,62281 \\
$50 \mathrm{mg} \mathrm{mL}$ & 97,93229 \\
$100 \mathrm{mg} \mathrm{mL}^{-1}$ & 97,27106 \\
$200 \mathrm{mg} \mathrm{mL}^{-1}$ & 87,04955 \\
$400 \mathrm{mg} \mathrm{mL}^{-1}$ & 54,18734 \\
$600 \mathrm{mg} \mathrm{mL}^{-1}$ & 19,60784 \\
$800 \mathrm{mg} \mathrm{mL}^{-1}$ & 0 \\
$1000 \mathrm{mg} \mathrm{mL}^{-1}$ & 0 \\
Positive control & 0 \\
\hline
\end{tabular}

In contrast, Nogueira et al. (2012) succeeded on finding inhibition in the hatchability of eggs in its three types of extract, using leaves, inflorescence and pseudostem; even surpassing the $40{ }^{\circ} \mathrm{C}$ in the processing of the extract. The major methodological difference was that the extract used was aqueous and non-alcoholic. In this mentioned work, inhibitions above $95 \%$ occurred for the three types of extracts at $2.5 \mathrm{mg} \mathrm{mL}^{-1} ; 5.0 \mathrm{mg} \mathrm{mL}^{-1}$ and $10.0 \mathrm{mg} \mathrm{mL}^{-1}$, obtained from the standardized extract: $100 \mathrm{mg} \mathrm{mL}^{-}$ 1. Such concentrations showed themselves lower than the concentrations that succeeded in this study: $160 \mathrm{mg} \mathrm{mL}^{-1}$ and $180 \mathrm{mg} \mathrm{mL}^{-1}$.

The proven effectiveness of tannin in this work contributes to the validation of the test compound in vitro for the helminth control in small ruminants.

\section{Conclusions}

This research concludes that alcoholic extract of Musa spp leaves has an effective action on the eggs and larvae of gastrointestinal nematodes from sheep, suggesting the anthelmintic effect of tannins from banana leaves and that they can be processed in the future for commercial application and being able to replace or act together with other anthelmintics.

\section{Acknowledgments}

The researchers want to thank Londrina State University and La Velle Goodwin for the support.

\section{References}

AYRES, M. C. C.; ALMEIDA M. A. O. Agentes antinematódeos. In: SPINOSA, H. S.; GORNIAK, S. L.; BERNARDI, M. M. Farmacologia aplicada à medicina veterinária. Rio de Janeiro: Guanabara Koogan, 2010, p. 476-488.

BESSA, N. G. F. de; BORGES, J. C. M.; BESERRA F. P.; CARVALHO, R. H. A.; PEREIRA, M. A. B.; CAMPOS S. L.; RIBEIRO, L. U.; QUIRINO, M. S.; CHAGAS JUNIOR, A. F.; ALVES, A. Prospecção fitoquímica preliminar de plantas nativas do cerrado de uso popular medicinal pela comunidade rural do assentamento Vale Verde - Tocantins. Revista Brasileira de Plantas Medicinais, Campinas, v. 15, n. 4, p. 692-707, 2013.

BIZIMENYERA, E. S.; GITHIORI, J. B.; ELOFF, J. N.; SWAN, G. E. In vitro activity of Peltophorum africanum sond. (Fabaceae) extracts on the egg hatching and larval development of the parasitic nematode Trichostrongylus colubriformis. Veterinary Parasitology, Amsterdam, v. 142, n. 3-4, p. 336-343, 2006.

BORGES, F. A.; ROSSINI, J. B.; VELLUDO, P. P.; BUZZULINI, C.; COSTA, G. H.; MOLENTO, M. B.; COSTA, A. J. Weak phenotypic reversion of ivermectin resistance in a field resistant isolate of Hemonchus contortus by verapamil. Pesquisa Veterinária Brasileira, Rio de Janeiro, v. 31, n. 9, p. 731-736, 2011. 
BRUNET, S.; JACKSON, F.; HOSTE, H. Efects of sainfoin (Onobrychis viciifolia) extract and monomers of condensed tannins on the association of abomasal nematode larvae with fundic explant. International Journal for Parasitology, Oxford, v. 38, n. 7, p. 783-790, 2008.

CEZAR, A. S.; CATTO, J. B.; BIANCHIN, I. Controle alternativo de nematódeos gastrintestinais dos ruminantes: atualidade e perspectivas. Ciência Rural, Santa Maria, v. 38, n. 7, p. 2083-2091, 2008.

COLES, G. C.; BAUER, C.; BOTGSTEEDE, F. H. M.; GEERTS, S.; KLEI, T. R.; TAYLOR, M. A.; WALLER, P. J. World association for the advancement of veterinary parasitology (W.A.A.P.) methods for the detection of anthelmintic resistance in nematodes of veterinary importance. Veterinary Parasitology, Amsterdam, v. 44, n. 1-2, p. 35-44, 1992.

FONSECA, L. D.; VIEIRA, T. M.; LÁZARO, S. F.; SILVA, M. L. F.; FERREIRA, A. V. de P.; BASTOS, G. A.; MORAIS-COSTA, F.; MARTINS, E. R.; DUARTE, E. R. Eficácia in vitro de extratos aquosos de plantas no controle de nematódeos gastrintestinais de bovinos. Acta Scientiae Veterinariae, Porto Alegre, v. 42, n. 1, p. 1-8, 2014.

FURTADO, S. K. Alternativas fitoterápicas para o controle da verminose ovina no estado do Paraná: testes in vitro e in vivo. 2006. Tese (Doutorado em Produção Vegetal) - Departamento de Fitotecnia e Fitossanitarismo. Setor de Ciências Agrárias. Universidade Federal do Paraná, Curitiba.

FURTADO, S. K.; NEGRELLE, R. B.; ZANIOLO, S. R.; KAPRONEZAI, J.; RAMOS, S. J.; SOTELLO, A. Efeito de Carica papaya L. (Caricaceae) e Musa paradisiaca (Musaceae) sobre o desenvolvimento de ovos de nematóides gastrintestinais de ovinos. Arquivos do Instituto Biológico, São Paulo, v. 72, n. 2, p. 191-197, 2005.
HOSTE, H.; JACKSON, F.; ATHANASIADOU, S.; THAMSBORG, S. M.; HOSKIN, S. O. The effects of tannin-rich plants on parasitic nematodes in ruminants. Trends in Parasitology, Philadelphia, v. 22, n. 6, p. 253261, 2006.

NOGUEIRA, F. A.; OLIVEIRA, L. N.; SILVA, R. B.; NERY, P. S.; VIRGÍNIO JUNIOR, G. F.; GERASEEV, L. C.; DUARTE, E. R. Anthelminthic efficacy of banana crop residues on gastrointestinal nematodes of sheep: in vitro and in vivo tests. Parasitology Research, Paris, v. 111, n. 1, p. 317-323, 2012.

OLIVO, C. J.; PEREIRA, L. E. T.; CARVALHO, N. M.; VOGEL, F. F.; HEINZMANN, B. M.; NEVES, A. P. Use of the banana plant (Musa spp.) for the control of parasites in domestic animals: from empiricism to science . Livestock Research for Rural Development, Cali, v. 19, n. 11, 2007. Available at: <http://www.lrrd. org/lrrd19/11/oliv19158.htm.\#158>. Accessed at: 3 may 2014.

RABEL, B.; McGREGOR, R.; DOUCH, P. G. Improved bioassay for estimation of inhibitory effects of ovine gastrointestinal mucus and anthelmintics on nematode larval migration. International Journal for Parasitology, Oxford, v. 24, n. 5, p. 671-676, 1994.

RAMOS, C. I.; BELlATO, V.; ÁVILA, V. S.; COUTINHO, G. C.; SOUZA, A. P. Resistência de parasitos gastrintestinais de ovinos a alguns antihelmínticos no estado de Santa Catarina, Brasil. Ciência Rural, Santa Maria, v. 32, n. 3, p. 473-477, 2002.

SCHMAHL, G.; AL-RASHEID, K. A. S.; ABDELGHAFFAR, F.; KLIMPEL, S.; MEHLHORN, H. The efficacy of neem seed extracts Tre-san, MiteStop on a broad spectrum of pests and parasites. Parasitology Research, Paris, v. 107, n. 2, p. 261-269, 2010. 